NBER WORKING PAPER SERIES

\title{
DOES SCHOOL CHOICE INCREASE \\ SCHOOL QUALITY?
}

\author{
George M. Holmes \\ Jeff DeSimone \\ Nicholas G. Rupp
}

Working Paper 9683

http://www.nber.org/papers/w9683

\section{NATIONAL BUREAU OF ECONOMIC RESEARCH 1050 Massachusetts Avenue \\ Cambridge, MA 02138}

May 2003

Holmes's research was supported by the East Carolina University College of Arts and Sciences Research Award for Spring 2001. The views expressed herein are those of the authors and not necessarily those of East Carolina University or the College of Arts and Sciences. Helpful comments were given by Eric Bettinger and participants at the 2001 Midwest Economics Association Meetings. Shuang Chen provided research assistance. The usual caveat applies. The views expressed herein are those of the authors and not necessarily those of the National Bureau of Economic Research.

CO2003 by George M. Holmes, Jeff DeSimone, and Nicholas G. Rupp. All rights reserved. Short sections of text not to exceed two paragraphs, may be quoted without explicit permission provided that full credit including Onotice, is given to the source. 
Does School Choice Increase School Quality?

George M. Holmes, Jeff DeSimone, and Nicholas G. Rupp

NBER Working Paper No. 9683

May 2003

JEL No. H4, I2, L1

\section{$\underline{\text { ABSTRACT }}$}

Federal "No Child Left Behind" legislation, which enables students of low-performing schools to exercise public school choice, exemplies a widespread belief that competing for students will spur public schools to higher achievement. We investigate how the introduction of school choice in North Carolina, via a dramatic increase in the number of charter schools across the state, affects the performance of traditional public schools on statewide tests. We find test score gains from competition that are robust to a variety of specifications. The introduction of charter school competition causes an approximate one percent increase in the score, which constitutes about one quarter of the average yearly growth.

George M. Holmes

A-438 Brewster Building

Department of Economics

East Carolina University

Greenville, NC 27858

holmesg@mail.ecu.edu
Jeff DeSimone

Department of Economics

College of Business Administration

4202 E. Fowler Avenue

BSN 3403

Tampa, FL 33620-5500 and NBER

desimonej@mail.ecu.edu
Nicholas G. Rupp

A-437 Brewster Building

Department of Economics

East Carolina University

Greenville, NC 27858

ruppn@mail.ecu.edu 


\section{Introduction}

School choice has become one of the most contentious public policy debates in the United States. Voters in Michigan and California rejected statewide voucher programs in 2000. Federal "No Child Left Behind" legislation implemented in Fall 2002 mandates limited school choice. One of the underlying assumptions motivating school choice is that introducing competition into education will increase school quality as schools face market pressures to attract students and their associated public funding. [

However, not only do we know little about the effect of school choice on the students who switch schools, we know even less about the effect on students who do not exercise the option to switch schools. In this paper, we explore the latter effect by examining the link between increased competition for students and the quality of schools facing competition. If the introduction of school choice, and the subsequent competition for students, encourages schools to improve quality, then the argument supporting the expansion of school choice are strengthened.

The expansion of North Carolina's charter school system provides a natural experiment for exploring this hypothesis. In the 1996-1997 school year, North Carolina had no charter schools. Just three years later nearly 100 charter schools were operating in North Carolina. This expansion of charter schools, which provides parents with more schooling options, is expected to spur improvement in the traditional public schools which have long dominated public and secondary education. We examine the expansion of the charter school system, both temporally and geographically, in order to estimate the effect of school choice on the performance of public schools.

Charter schools are public schools that are founded by community leaders and parents..$^{2}$ Charter schools receive public funds but are allowed greater curricular flexibility than traditional public schools. 3] Across the United States, the charter school system has expanded rapidly. According to the National Center for Education Statistics, approximately 2,000 charter schools operated in 2000-2001 (Hoffman, 2002). The enrollment mechanism varies by state, but typically students can disenroll from the assigned traditional school and enroll in a charter school.

\footnotetext{
${ }^{1}$ For example, see Friedman (1962) for a discussion.

${ }^{2}$ For more on charter schools, see Geske, Davis and Hingle (1997).

${ }^{3}$ We define "traditional school" as the public school that is managed by the local education agency, in contrast with the "charter school". The term "traditional" is not meant to suggest that charter schools necessarily adopt an atypical curriculum.
} 
Two justifications are commonly offered for charter schools. The first is that increased curricular flexibility allows charter schools to adapt their curricula to particular needs of their student populations. For example, some charters specialize in the arts, while others specialize in vocational education. More common are charters that focus on traditional subjects, but use an atypical curriculum. The potential benefit from these schools, however, is limited to students who enroll in the charter school.⿴囗十

The second justification is that the infusion of competition into the public education system provides an incentive for traditional schools to increase quality. This follows the standard economic argument that competition forces firms to increase quality and/or lower price. When a charter school opens, the traditional school, which previously held a monopoly on public education in a feeder district, faces the prospect of losing students to the new competitor. To the extent that the school's agent (ostensibly a principal) experiences disutility from a decline in enrollment, this might lead to an increase in the traditional school's quality in order to retain students. Such disutility might result from a decline in stature of the school in the community, lessened prospects for career advancement, a loss of personnel and budget provided by the funding agency, or a decrease in job satisfaction. Depending on the form of the public education cost function, a decrease in enrollment might also increase average costs and lower the quality of instruction for the remaining students.

This second effect is particularly interesting from a policy perspective. The idea that empowered parents can "vote with their feet" (Tiebout, 1956) is the primary tenet behind other current experiments in school choice. For example, while some parents desire vouchers in order to switch their children from the assigned traditional public school to a private school, others are likely interested in vouchers so they can credibly threaten to disenroll the children from the traditional school unless improvements are made. By exploring the degree to which the availability of charter schools affects the quality of competing traditional schools, we add to the debate on school choice.

Current evidence that links school choice and quality is limited, but typically finds some quality gains to choice. Hoxby (2000a) looks at intra-district choice, finding some benefits to competition. Blair and Staley (1995) report that test performance in a school district is correlated with performance in neighboring districts, though their results may be partially explained by spatial

\footnotetext{
${ }^{4}$ There may be peer effects on students remaining in traditional schools as charter-bound students disenroll (e.g. Hoxby, 2000b), but these effects are likely small relative to the benefits received by charter school enrollees. Furthermore, such peer effects may be negative depending on the types of students disenrolling.
} 
correlation. Borland and Howsen (1992) find weak evidence that lower school district concentration leads to higher achievement. Bettinger (1999) finds no gains to competition from Michigan charter schools. Rouse (1998) finds that the Milwaukee voucher program increased student achievement. Hoxby (2002) examines the effects of vouchers in Milwaukee and charter schools in Michigan and Arizona and finds productivity and achievement gains from increased choice. Cullen, Jacob, and Levitt (2000) use Chicago Public School data to analyze the effect of choice on the students who change schools, obtaining mixed results. Finally, Greene and Forster (2002) report gains to competition as measured by an index of the distance between traditional schools and charters.

We contribute to the school choice literature by exploiting an expansion of the North Carolina charter school system in combination with extensive school achievement data. Our hypothesis is that the expansion of the charter school system has encouraged traditional schools to increase achievement by offering greater school choice to North Carolina parents. Our results generally support this hypothesis. In particular, we find that the closer a charter school is to a traditional school (and hence the greater the competition facing the traditional school), the greater the achievement gains. These results persist across a wide set of models. The gain is not inconsequential, since the average achievement increase due to charter school competition (1 percent) is about one fourth of the average yearly increase.

The remainder of the paper is organized as follows. Section 2 develops a theoretical model and section 3 presents the econometric model. Sections 4 and 5 discuss the data and the estimation results. Section 6 summarizes the main findings, addresses limitations, and offers suggestions for future research.

\section{Conceptual model}

Consider an agent (e.g. a school principal) who manages the sole traditional public school in the feeder district. Parents can choose for their children to attend either the traditional school or a competing charter school that has a price of attendance $p$. . Assume that the utility function of the agent,

\footnotetext{
${ }^{5}$ For linguistic convenience, we adopt the convention that the parents choose the school that their children attend. This is reasonable given that our data consist of third through eighth graders.
} 


$$
U(M, e)
$$

has two components, effort exerted by the agent $(e)$ and membership of the school $(M) . M$ is a demand function defined as

$$
M(q(e), p)
$$

where $q$ is the quality of the traditional school.

We assume that $U$ is decreasing in $e$, increasing in $M$, and concave in each. Since $M$ is a demand function, it is increasing in both the price of a substitute good $(p)$, and the quality $(q)$. The agent can increase the quality of the school by exerting more effort, perhaps through more staff meetings, greater vigilance of instruction quality, or implementation of after-school programs, although the second derivative of $q(e)$ is negative.

The agent chooses $e$ to maximize

$$
U(e, M(q(e), p))
$$

The first order condition is

$$
U_{e}+U_{M} M_{q} q_{e}=0
$$

where subscripts denote partial derivatives. Equation 1 indicates that at the optimal effort level the marginal disutility from effort equals the marginal utility stemming from the increased membership that results from the positive impact of additional effort on school quality.

We examine the impact of increased charter school availability on traditional school test scores, or in terms of the model, the effect of decreases in $p$ on $q$. Since $\frac{\partial q}{\partial e}>0$, the sign of $\frac{\partial q}{\partial p}$ is the same as the sign of $\frac{\partial e}{\partial p}$. Using the implicit function theorem, it can be shown that a sufficient condition for $\frac{\partial e}{\partial p}<0$ is

$$
\frac{\partial^{2} U}{\partial e \partial M}<0
$$


That is, a decrease in cost of charter school attendance increases the quality of the competing traditional school if the marginal disutility of effort is increasing in membership or, symmetrically, the marginal utility of membership is decreasing in effort. This condition implies that as enrollment in the traditional school increases, the agent has less incentive to exert substantial effort. Alternatively, at high levels of effort, increases in membership provide little benefit.

We define the traditional school's competitor as the nearest charter school and examine whether the distance to the competitor influences the performance of the traditional school.[ Since charter schools charge no tuition, a major component of the price of attending the competitor is travel cost. Travel cost, in terms of lost wages, depreciation of the transport vehicle, and lost leisure time, increases as distance from the traditional school increases, holding other factors constant. Thus, we use the distance to the nearest charter school as a proxy for travel cost — and the price of attendance $p$ - to examine whether charter school competition increases traditional school quality.

Private schools and neighboring traditional school districts also compete with traditional schools. We ignore these two additional sources of competition because the cost of switching to either is substantially higher than that of switching to a charter school. Unlike traditional and charter schools, tuition at private schools is considerable. Meanwhile, switching between neighboring traditional school districts typically requires the family to move its residence. Thus, threats to transfer to a nearby charter school are more credible than threats to transfer to a neighboring traditional or private school.

\section{Econometric Model}

The primary effect of interest is how a change in the price of charter school attendance, as represented by distance to the nearest charter school, affects the quality of the traditional school. Our measure of quality is the achievement of the students in the traditional school as measured by end-of-year test scores. We therefore estimate the following test score production function:

\footnotetext{
${ }^{6}$ Our use of distance as the relevant cost component follows originally from Hotelling (1949), who proposed that travel cost, which is a function of distance, is an important determinant of the demand for recreational goods. Smith and Kaoru (1990) perform a meta-analysis of the literature on the effects of travel cost in the recreational economics literature. In the education literature, distance has been extensively used as a determinant for school attendance. For example, in a study of school choice in Pakistan, Alderman, Orazem, and Paterno (2001) find that changes of only one kilometer in distance to the nearest school have a substantial effect on the probability of attending that school. Collins and Snell (2000) find (in UK data) that students living farther from a school were less likely to attend it. Goldring and Hausman (1999) find that distance was an important consideration for Saint Louis parents.
} 


$$
S C O R E_{i t}=\alpha S C O R E_{i t-1}+\gamma D I S T A N C E_{i t}+\beta X_{i t}+\mu_{i}+\varepsilon_{i t}
$$

This "value-added" specification for test score production is commonly used in the literature. Specifically, the lagged test score accounts for underlying student quality. We include observed time-specific characteristics of the school $X_{i t}$ that influence achievement. Error components $\mu_{i}$, which is time invariant, and $\varepsilon_{i t}$, which is transitory, are unobserved. The parameter of interest is $\gamma$, the effect of price on quality.

We estimate three types of models. First, we estimate cross-sectional models by year. Our data, however, are longitudinal, and cross-sectional models yield inefficient estimates by disregarding potentially important information. To account for the panel nature of the data and to test for robustness, we estimate panel models using both the Arellano-Bond (1991) procedure for dynamic panel models and a semi-parametric maximum likelihood estimator.

Because the lagged SCORE term and the $\mu_{i}$ term (a school-specific time-invariant component) are correlated, OLS estimation will be inconsistent. We therefore estimate the cross-sectional models by standard instrumental variables techniques. The Arellano-Bond (1991) procedure is an instrumental variables method that accounts for the inclusion of the lagged dependent variable in a longitudinal framework.

The maximum likelihood estimates are consistent if the $\mu_{i}$ term is integrated out. That is, the individual school's likelihood is

$$
L_{i}(\Theta \mid X)=\int\left(\prod_{t}\left[f\left(S C O R E_{i t} \mid S C O R E_{i t-1}, X_{i t}, \mu\right)\right] f\left(S C O R E_{i 0} \mid, Z_{i t}, \mu\right) d \mu\right),
$$

where the second term is the initial condition. Rather than specify the distribution of the $\mu_{i}$ and integrate over the assumed density, we use a semi-parametric method originally suggested for survival analysis by Heckman and Singer (1984) and subsequently generalized to a wider class of models by various researchers including Angeles, Guilkey and Mroz (1998), Cutler (1995), Goldman, Leibowitz, and Buchanan (1998), and Taber (2000). This class of models - known as discrete factor models - estimates the density of the $\mu_{i}$ within the likelihood maximization process by estimating 


$$
L_{i}(\Theta \mid X)=\sum_{m=1, \ldots M} \pi_{m}\left(\prod_{t}\left[f\left(S C O R E_{i t} \mid S C O R E_{i t-1}, X_{i t}, \bar{\mu}_{m}\right)\right] f\left(S C O R E_{i 0} \mid, Z_{i t}, \bar{\mu}_{m}\right)\right)
$$

where $\pi_{m}=\operatorname{Pr}\left(\mu=\bar{\mu}_{m}\right)$. The $\bar{\mu}_{m}$ and $\pi_{m}$ are estimated within the model.

\section{Data}

The data for this study come primarily from three sources. School test performance data are provided by the North Carolina Department of Public Instruction (NCDPI). Beginning in 19961997, NCDPI has tested students at the end of each school year as part of its "ABC's of Public Education" program. These end-of-year tests are taken statewide by all students in grades three through twelve. Tests vary by grade. We analyze outcomes of math, reading, and writing tests taken by students in grades three through eight. The measure we use is the school-level "performance composite", which NCDPI computes as the percentage of tests taken that meet a NCDPI defined achievement standard. The performance composite is a combination of the math, reading, and writing scores, so that the performance composite reflects NCDPI's estimate of the percent of students with satisfactory achievement. Since the performance composite is widely reported and disseminated by the media, traditional schools have added market pressure to improve test performance. Although parents would likely suspect which schools are "good" and "bad" in the absence of test results, publication of the NCDPI scores provides parents with quantitative information on which they can form their judgements if they choose.

The use of test scores to measure of school quality is potentially contentious. Researchers have used various alternative measures of school quality, such as labor market outcomes (e.g., Card and Krueger, 1992) and further educational attainment (e.g. Krueger, 1999; Betts, 2001) of attendees. Hanushek (1979) argues that test scores proxy school quality relatively well in earlier grades. Hence, this paper examines only elementary and middle school test scores.

Our price variable is the distance from the traditional school to the nearest charter school. To generate this measure, we map the latitude and longitude of traditional schools and charter schools

\footnotetext{
${ }^{7}$ For more details regarding this estimation method, consult Angeles, Guilkey, and Mroz (1998).
} 
throughout the state, identify the closest charter school to each traditional school, and compute

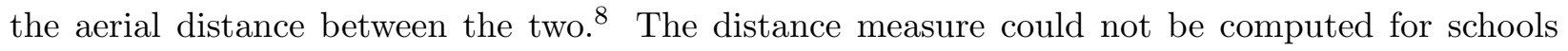
with addresses that were not mappable (about 100 schools, or seven percent of the sample). These schools listed addresses with rural routes or streets that could not be located. These schools, which are disproportionately rural, are thus excluded from the analysis.

The third major data source is the National Center for Education Statistics' Common Core of Data (CCD). The CCD contains measures of the student population, including racial and ethnic composition, the percentage qualifying for free lunch, and the total enrollment of the school. These files also contain information on personnel counts, allowing us to use the ratio of pupils to full-time equivalent instruction personnel to proxy for class size. Although Hanushek et al (1996) find that the use of school-level measures may lead to biased estimators, neither the CCD nor NCDPI provide class size measures.

To balance our panel, we exclude schools with missing test performance measures for any year during our sample period which spans from 1996-1997 to 1999-2000. This assumes that the sample attrition process is random. Schools with missing test performance data include those that did not report $\mathrm{ABC}$ results in a year (due to insufficient student testing or some other technical reason), began operating after 1996-1997, or ceased operations before 1999-2000. We also drop schools located in three North Carolina Outer Banks counties with substantial water boundaries, making the straight-line distance a poor proxy for actual travel time to and from these localities. One additional factor that might affect test performance is the degree of urbanization. Thus we calculate the county's population density and include it as a regressor.

\section{Results}

\subsection{Summary statistics}

We begin by describing the number of charter schools in North Carolina. Table 1 shows that the charter school system has grown substantially during the sample period. In 1996-1997, there were no charter schools. The following year, there were 28 charter schools in operation. By 1999-2000,

\footnotetext{
${ }^{8}$ Bettinger (1999) uses the number of charter schools within a given radius as a measure of charter school competition.
} 
there were 74. Despite the rapid growth in the charter school system, charter school attendees comprise just over one percent of public school enrollment in 2000-2001.

Table 2 presents various measures of distance to the nearest charter school for the sample years. As the number of charter schools nearly tripled, the average distance to the closest charter school has fallen by about one-third, from $32 \mathrm{~km}$ in 1997-1998 to $21 \mathrm{~km}$ in 1999-2000. As an alternative to distance (or the log of distance in some regressions), we calculate five indicator variables that equal 1 if and only if the traditional school is within a given number of kilometers $(5,10,15,20$, and 25 kilometers) of the nearest charter. For example, the distance to the nearest charter school is less than five kilometers for about 9 percent of traditional schools in 1997-1998, but over twice as many schools were within 5 kilometers in 1999-2000. We also calcaulate an indicator for whether a charter school is operating in the same county as the traditional school, the mean of which also increases over time.

The influence of a nearby charter school on traditional school performance depends, in part, on the credibility of students' threats to switch to the charter. Threats are more credible as the distances between the schools decreases. In order to frame the distances over which charter schools might affect traditional school enrollment, we examine separate data on approximately 2,000 North Carolina students in grades three through eight who switch from a traditional school to a charter school. The median distance between the two schools for these switchers is about 6 kilometers, with a 95th percentile of around 22 kilometers. Although these data represent actual rather than potential migration patterns, these statistics suggest that effects of charter schools beyond 25 kilometers from a traditional school should be small.9

Figure 1 maps North Carolina counties and their charter school status during the three sample years. It is evident that counties in metropolitan statistical areas are more likely to contain a charter school. There is also considerable variation over time with many new charter schools opening each year. Figure 2 tabulates distance from the traditional school to the nearest charter by whether any charter was operating in the same county as the traditional school in 1999. For example, ninety percent of schools in counties with a charter school are located within $20 \mathrm{~km}$ of the charter.

Table 3] summarizes the mean performance composite among traditional schools and changes

\footnotetext{
${ }^{9}$ We also spoke with a charter school administrator in North Carolina who indicates that his school draws students primarily from four nearby schools located approximately $2,5,6$, and $9 \mathrm{~km}$ from the charter.
} 
from the previous year. The mean performance composite increased over time from roughly 67 in 1996-97 to 75 in 1999-2000. The yearly increase fell over time, though, from around 4 in 1997-98 to just over 1 in 1999-2000.

Table 1 presents sample summary statistics. In the typical school, approximately three percent of students are Hispanic, thirty-two percent are African-American, and thirty-eight percent are eligible for free lunch. On average schools have 15 students per faculty member, an enrollment of 566 students, and a performance composite of about 72 .

\subsection{Cross-section regressions}

We begin by exploring cross-section regression models. Beyond the potential inconsistency from the use of the lagged dependent variable as a regressor, this first econometric specification has two possible limitations. First, the lagged performance composite score proxying for ability is measured with error, because the score is an imperfect measure of underlying student quality. charter school placement, and thus distance from the traditional school to the nearest charter school, may be a function of traditional school quality. For example, charters may locate in areas with aboveaverage student quality in order to "skim" the high-performing students and appear to be very effective. In this situation, a cross-section regression would indicate a beneficial effect of charter school competition because the average traditional school facing competition has higher quality students than the average school not facing competition. Alternatively, charters may originate in locales in which parents are dissatisfied with the performance of the traditional school. If students in these areas have below-average achievement, competition would appear detrimental to traditional school performance because the average school facing competition has lower quality students than the average school not facing competition.

We examine the possibility that charter schools are endogenously placed in cross-section regressions in which distance is instrumented by county-level factors thought to influence the location of charter schools in North Carolina. W Over all distance variable specifications, Hausman tests of exogeneity are insignificant, implying that the distance measure can be treated as exogenous. Bettinger (1999) used distance to the nearest public university for which the governor (a charter school

\footnotetext{
${ }^{10}$ Instuments include county-level factors such as the proportion of students African-American, the average performance composite, and the total number of students. The instrument set passes tests of both power and overidentification at conventional levels.
} 
proponent) appoints the board as an instrument for charter school competition, motivated by the fact that in Michigan universities issue the charters for charter schools. Since school systems issue the charters in North Carolina, there is little theoretical justification for using a similar instrument in our regressions. M Moreover, North Carolina charter schools are quite heterogeneous in focus and history, including some schools that converted from traditional public or private administration. Thus, there is no single model that explains how charter schools are instituted in North Carolina. Therefore, the remainder of the paper assumes that charter school placement, and thus distance to the nearest charter school, is exogneous.

The cross-sectional models estimate the effect of five different distance measures. Two of these are parametric: the number of kilometers to the nearest charter school and the log of this measure. We also explore three binary indicators. Two of these signal whether the traditional school is within 10 or $20 \mathrm{~km}$, respectively, of the nearest charter school.[ The third is an indicator for whether a charter school is located in the county that year. Since our hypothesis predicts that traditional school quality will decrease as the distance to the nearest charter increases, the predicted coefficients are negative for parametric measures and positive for the indicators.

Table (5) summarizes cross-sectional regression results. A separate regression is estimated for each of the three sample years and for each of the five distance measures, resulting in fifteen separate models. Eight of the fifteen distance estimates are significantly different from zero and all have the expected sign. In the first and third year, all three distance indicators are significant. In 1997-98, the magnitude of the charter effect is invariant to whether the charter is within 10 or $20 \mathrm{~km}$, while in 1999-2000, the magnitude is twice as great for the shorter distance. This pattern, as well as the larger coefficient for "charter in county" in 1997-98, is consistent with the dramatic growth of the charter system during these two years: in 1999-2000 more traditional schools were likely to have charters within the county and charters within $20 \mathrm{~km}$. In these 2 years, the only parametric measure that is significant is the log of distance in 1999-2000. The results for 1998-99 are the opposite, since distance is significant but no other measures are.[3]

\footnotetext{
${ }^{11}$ We estimated IV models analogous to those of Bettinger (1999). Although distance to the nearest public university passed instrument validity tests, Hausman tests failed to reject its exogeneity in the test performance equation.

${ }^{12}$ Similar results are found for the five, fifteen, and twenty-five kilometer indicators.

${ }^{13}$ Schools may experience large shifts in enrollment if nearby schools open or close. To test for robustness, we run the IV models on the subsample of schools with yearly changes of enrollment of less than five percent. The results are, in general, more statistically and economically significant.
} 
The relevant policy question, however, is what happens to the quality of traditional schools after the onset of charter school competition. We explore this question, most appropriately addressed from a longitudinal perspective, in the next two subsections.

\subsection{IV panel models}

Table 6 presents results from the Arellano-Bond (1991) panel IV models. Again, we instrument the once-lagged score with the twice-lagged score to account for measurement error. Model (1) uses the natural log of the kilometers from the nearest charter school to account for the degree of competition. The estimated elasticity of Model (1) is .003 which is statistically insignificant. This elasticity might seem small at first blush, but recall that it is conditional on the previous year performance composite. The average performance composite gain in 1999-2000, for example, is 1.11 points (1.7 percent), so (ignoring statistical significance) halving the distance to the nearest charter would bring about an increase of just less than ten percent of the average achievement gain.

Models (2) through (6) control for charter school competition using indicators for whether a charter school was operating within a given distance. In all of these models, charter school competition raises the performance composite of the traditional school. The effect is significant at standard significance levels for all indicators except within five kilometers, and is nearly significant for that indicator. In all five cases, charter school competition increases traditional school performance by about one percent. This represents more than one-half of the average achievement gain of 1.7 percent in 1999-2000.

The magnitudes of these effects are roughly two to five times as large as that of decreasing the student-faculty ratio by 1 . Introducing school choice seems like a promising alternative to lowering class size, which has received substantially more public policy attention, and is likely more cost-effective in the context of charter schools. Since state funding follows the student, an increase in the charter school system implies no increase in spending. [4] For instance, in 2002, the North Carolina Governor's Office proposed a $\$$ US 26 million increase in the state budget to reduce average class size by roughly 1.8 students. Ignoring statistical significance, this would increase scores by approximately .36 percent, about one-third of the increase attributable to the opening of

\footnotetext{
${ }^{14}$ Technically, the state may even save money from charter school expansion, since, for example, the state provides no capital funding for charter schools.
} 
a neighboring charter school.

Model (7) uses an indicator for whether a charter school is operating in the same county as the traditional school. The point estimate on this parameter is again positive and similar in magnitude to the other indicators, although it is marginally insignificant.

\subsection{Maximum likelihood models}

Finally, we specify the maximum likelihood model of Equation 8, which accounts for the timeinvariant unobserved characteristics as well as the initial condition. The endogeneity is incorporated by points of support - one point of support assumes that there is no time-invariant heterogeneity. As the points of support increase, the model estimates more support points of the heterogeneity. If heterogeneity exists, then the one point of support model will yield inconsistent results. Table [7 shows the results, which are similar to those obtained in the cross-sectional and panel IV regressions.15 Two distinct patterns emerge. First, the estimated effect of competition falls as distance increases, as expected, with just one exception: the estimated effect of being $15 \mathrm{~km}$ is smaller than that of the estimated effect of begin within $20 \mathrm{~km}$ of a charter. Traditional schools within 5 kilometers of a charter experience a one percent achievement gain; traditional schools within 25 kilometers experience only about half of that gain. Second, unobserved heterogeneity has very little impact on the distance indicator coefficient estimates. Although specification tests reject the parsimonious one point model (which assumes that there is no unobserved heterogeneity), the quantitative effect on the estimates of moving to the four point model is inconsequential.

\subsection{Is Selection Driving These Results?}

One possible alternative explanation for improved traditional school achievement when a charter school opens nearby is migration from the traditional school to the charter by lower performing students. Three pieces of evidence, however, suggest that if anything, the opposite phenomenon occurs in our sample: students switching from traditional to charter schools are above average performers.

We first look at within-school variation in achievement over time. Enrollment increases in

\footnotetext{
${ }^{15}$ For brevity, we present results only for models with 1 and 4 points of support. Full results are available from the authors upon request.
} 
traditional schools within ten kilometers of a charter school were almost two percent less than those in other traditional schools, suggesting that some migration from the traditional school to the charter school occurs. Repeating this comparison for the percentages of students eligible for free lunch and who are African-American, two populations with lower than average test scores, we find that relative sizes of these populations increase in traditional schools within ten kilometers of a new charter. To the extent that these populations proxy for below-average scoring students, our estimated gains to competition are in spite of, rather than a consequence of, a change in student population.

Next we explore this issue using student-level data. Although we lack comprehensive individual student tracking data necessary to follow all students longitudinally, we have once-lagged test scores for all students contributing current scores. To examine the effect of attrition, we calculate the average once-lagged score for each school-grade and test subject (math and reading), a measure of previous year ability. For example, we obtain the average 1998-99 math score for all students in school $s$, grade 4, in 1999-2000. If there is no systematic exiting from traditional schools, then the change in the once-lagged score should be independent of whether a competing charter school opens. That is, if low-performing students leave a traditional school for a new charter school in 1999-2000, then the change in average score from 1997-98 to 1998-99 for the students attending the traditional school in 1998-99 and 1999-2000 should be greater than the corresponding change for an otherwise identical school not facing new charter school competition.

This idea can be tested by estimating equation (9), where subscripts denote school ( $s$ ), cohort $(c)$, and time $(t)$. As described above, LAGSCORE represents the once lagged performance composite and COMPETE is a dummy for whether a charter school is located within $10 \mathrm{~km}$. Unobserved effects include time effects $\left(\tau_{t}\right)$, school-cohort effects $\left(\mu_{s, c}\right)$, and idiosyncratic schooltime-cohort effects $\left(\varepsilon_{c, s, t}\right)$. Parameter $\gamma$ thus measures whether the change in the lagged score differs by whether the school faced charter school competition. If lower scoring students switch from traditional schools to competing charter schools, and the result is an increase in the observed achievement, then $\gamma$ will be positive.

$$
\operatorname{LAGSCORE}_{s, c, t}=\alpha+\tau_{t}+\operatorname{COMPETE} E_{s, c, t} \gamma+\mu_{s, c}+\varepsilon_{s, c, t}
$$


Table 8 reports the estimates of equation (9) for all six cohorts that we can follow longitudinally. Of the twelve cohort-subject pairs beginning with grade 3 in 1997-1998 and ending with grade 8 in 1998-1999 for both subjects (reading and math), only three experience a significant change in lagged test score, all of which are lower after the introduction of a charter school. This provides evidence that above-average students are more likely to exit traditional schools for charters than below-average students.

Finally, for those students that we are able to identify, we examine the performance of students who switched from a traditional school to a charter.16 We find that approximately 75 percent of those who switched had a higher score than the average score in the traditional school the year before they left. This is direct evidence that charter-induced growth in traditional school performance is not a manifestation of an exodus of low-scoring students.

In sum, traditional schools experience net gains in performance despite a decrease in average student quality (in some cohorts), suggesting that our estimated effects of charter school competition provide a lower bound for the true effect.

\section{Conclusion}

Using North Carolina data on charter school location and achievement test results, we explore the effect of school choice on school quality. We find traditional school achievement gains to charter school competition across a wide set of models. Overall, the results imply an approximate one percent increase in achievement when a traditional school faces competition from a charter school. This increase represents approximately one quarter of the mean standard deviation of observed gains, suggesting a considerable return to school choice.

Our results conflict with Bettinger's (1999) finding that charter school competition has no effect on traditional schools, but this difference may be due to different pre-charter competitive environments in North Carolina and Michigan. North Carolina has 117 independent traditional school districts while Michigan has over 500. North Carolina school districts correspond roughly to counties, so residents have less ability to exert Tiebout choice over their school districts. Michigan

\footnotetext{
${ }^{16}$ Identifying students who switch involves finding unique matches on test scores, race, gender, and birthdate. We search for unique matches only within a county for those students who do not match within a school between years. We can identify 2,140 students who switch from a traditional school to a charter school.
} 
parents, in contrast, have a much larger number of school districts within a small distance of their residences. $[7$

A caveat is that we make two sets of simplifying assumptions regarding school choice. First, we ignore all non-charter school intra-system choices. For example, almost seventy percent of North Carolina school districts offer some form of school choice such as intra-district transfers, magnets, and year-round schools (North Carolina Office of Lieutenant Governor, 2000). Combined with private and alternative schools, and home-schooling, residents of most North Carolina counties have some form of school choice, such as intra-district transfers, magnet schools, and year-round schools.. Ignoring these alternatives leads to an overestimate of the distance to the nearest competitor. The direction of any resulting bias is not clear. However, if one interprets the results as the effect of charter school choice, rather than school choice in general, then this problem is eliminated.

Second, we make some important assumptions about transferring into a charter school. Interdistrict transfers are allowed in the model. It is assumed that there are open seats in the charter so that a threat to disenroll is credible. We also assume that the size of the charter has no effect on the impact of competition, though it is possible that this impact will increase with size of the charter.

Nevertheless, this paper adds to the literature on school competition using a simple model that incorporates cost and quality and heretofore unanalyzed data. The results suggest important gains in traditional school achievement due to the introduction and growth of charter school choice.

\footnotetext{
${ }^{17}$ For example, Kent County (Michigan) and Wake County (North Carolina) have similar populations and land areas. Although Wake County has one (traditional) school district, Kent County has nineteen.
} 


\section{References}

Alderman, Harold, Peter F. Orazem, and Elizabeth M. Paterno. 2001. School Quality, School Cost, and the Public/Private School Choices of Low-Income Households in Pakistan. Journal of Human Reources: 304-326.

Angeles, Gustavo, David K. Guilkey, and Thomas A. Mroz. 1998. Purposive Program Placement and the Estimation of Program Effects: The Impact of Family Planning Programs in Tanzania. Journal of the American Statistical Association, 93(443): 884-899.

Arellano, M. and S. Bond, 1991, Some Tests Of Specification For Panel Data: Monte Carlo Evidence And An Application To Employment Equations, Review Of Economic Studies, 58, $277-297$.

Bettinger, Eric. 1999. The Effect of Charter Schools on Charter Students and Public Schools. National Center for Study of Privatization in Education, Teachers College, Columbia University.

Betts, Julian R. 2001. The Impact of School Resources on Women's Earnings and Educational Attainment: Findings from the National Longitudinal Survey of Young Women. Journal of Labor Economics, 19(3): 635-657.

Blair, John P. and Sam Staley. 1995. Quality Competition and Public Schools: Further Evidence. Economics Of Education Review, 14(2): 193-198.

Borland, Melvin V. and Roy M. Howsen. 1992. Stuent Achievement and the degree of Market Concentration in Education. Economics of Education Review, 11(1): 31-39.

Card, David and Alan Krueger. 1992. School quality and black-white relative earnings: A direct assessment. Journal of Political Economy 100: 1-40.

Collins, Alan and Martin C. Sell. 2000. Parental Preferences and Choice of School. Applied Economics, vol. 32, no. 7, pp. 803-13

Cutler, David M. 1995. The Incidence of Adverse Medical Outcomes under Prospective Payment. Econometrica. 63 (1), pp. 29-50 
Fiske, Edward B. and Helen F. Ladd. 2000. When Schools Compete: A Cautionary Tale. Brookings Institution Press: Washington, D.C.

Friedman, Milton. 1962. Capitalism and Freedom. University of Chicago Press.

Geske, Terry G., Douglas R. Davis, and Patricia L. Hingle. 1997. Charter Schools: A Viable Public School Choice Option? Economics of Education Review, 16(1): 15-23.

Goldman, Dana P., Arleen Leibowitz, and Joan L. Buchanan. Cost-Containment and Adverse Selection in Medicaid HMOs. Journal of the American Statistical Association, vol. 93, no. 441, March 1998, pp. 54-62.

Goldring, E. B., and C. S. Hausman. 1999. Reasons for Parental Choice of Urban Schools. Journal of Educational Policy, 14(5): 469-490.

Greene, Jay P. and Greg Forster. 2002. Rising to the Challenge: The Effect of School Choice on Public Schools in Milwaukee and San Antonio. Mimeo, The Manhattan Institute.

Hanushek, Eric A. 1979. Conceptual and Empirical Issues in the Estimation of Educational Production Functions. Journal of Human Resources, 14(3): 351-388.

Hanushek, Eric A., Steven G. Rivkin, and Lori L. Taylor. 1996. Aggregation and the Estimated Effects of Schools Resources. Review of Economics and Statistics, 78(4): 611-627.

Hoffman, Lee. Overview of Public Elementary and Secondary Schools and Districts: School Year 2000-01. National Center for Education Statistics.

Hoxby, Caroline Minter. 2000a. Does Competition Among Public Schools Benefit Students and Taxpayers? American Economic Review, 90(5): 1209-1238.

Hoxby, Caroline. 2000b. Peer Effects in the Classroom: Learning from Gender and Race Variation. NBER Working Paper No. 7867.

Hoxby, Caroline. 2002. School Choice and School Productivity (Or Could School Choice be a Tide that Lifts all Boats?). NBER Working Paper No. 8873.

Krueger, Alan. 1999. Experimental Estimates of Education Production Functions. Quarterly Journal of Economics, vol. 114, no. 2, pp. 497-532 
Levin, Henry M. 1991. The Economics Of Educational Choice. Economics Of Education Review, $10(2): 137-158$

Manski, Charles F. 1992. Educational Choice (Vouchers) and Social Mobility. Economics of Education Review, vol. 11, no. 4, December 1992, pp. 351-69.

North Carolina Office of the Lieutenant Governor. 2000. The Status of School Choice in North Carolina.

Public Schools of North Carolina. 1998a. Selected Characteristics of Charter Schools, Programs, Students, and Teachers. North Carolina Department of Public Instruction, Division of Accountability Services, Evaluation Section.

Public Schools of North Carolina. 1998b First Year's Impact of North Carolina Charter Schools on Local Education Agencies and Their Schools. North Carolina Department of Public Instruction, Division of Accountability Services, Evaluation Section.

Taber, Christopher R. 2000. Semiparametric Identification and Heterogeneity in Discrete Choice Dynamic Programming Models. Journal of Econometrics, 96(2): 201-229.

Tiebout, Charles M. 1956. A Pure Theory Of Local Expenditures. The Journal Of Political Economy, 64 (5):416-424 
Metro Status Not Metro
7. Metro

Number Years with at least one charter in county None

One Year

Two Years

Three Years

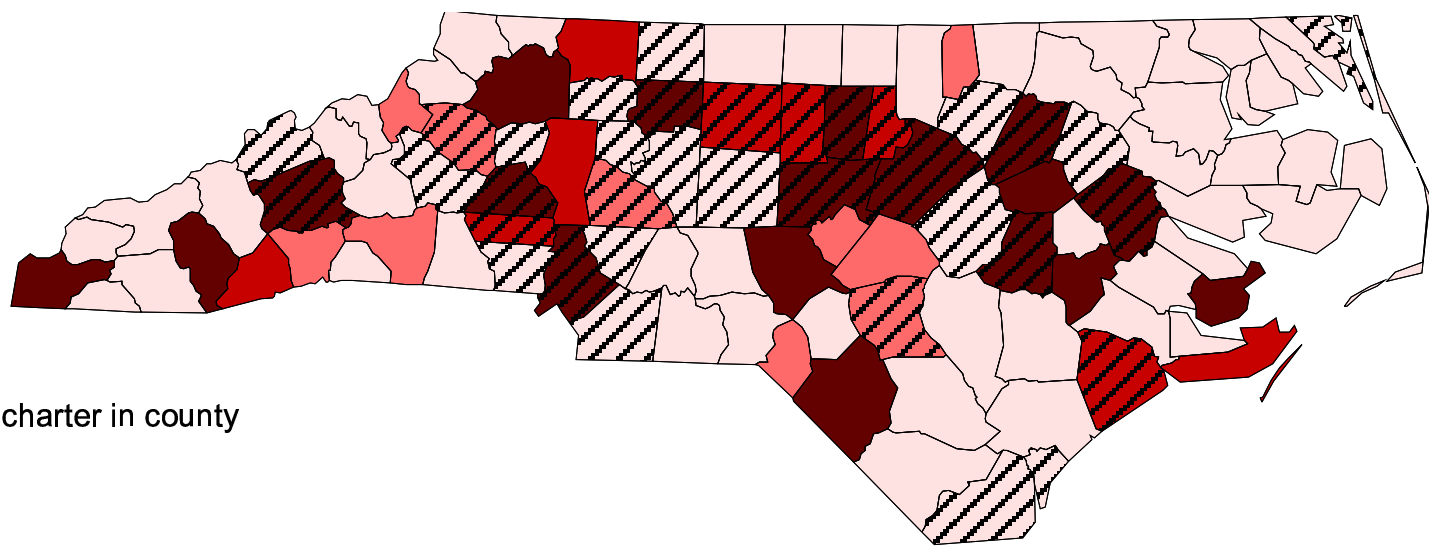

Figure 1: North Carolina Charter Schools: 1997-2000

Years refer to academic school years 1997-98, 1998-99, and 1999-2000. 


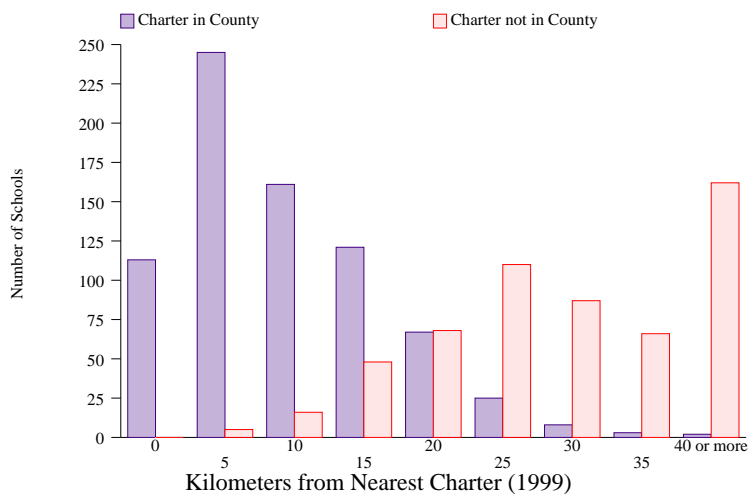

Figure 2: Distribution of distance from nearest charter for schools with and without charters in the same county. 
Table 1: Charter Schools in North Carolina

\begin{tabular}{lcccc} 
Year & $\begin{array}{c}\text { Total Public } \\
\text { Enrollment }\end{array}$ & $\begin{array}{c}\text { Charter School } \\
\text { Enrollment }\end{array}$ & $\begin{array}{c}\text { Percent of Public } \\
\text { Students in Charter }\end{array}$ & $\begin{array}{c}\text { Charter Schools } \\
\text { in Operation }\end{array}$ \\
\hline $1997-1998$ & $1,208,368$ & 4,456 & $0.37 \%$ & 28 \\
$1998-1999$ & $1,229,929$ & 8,183 & $0.67 \%$ & 52 \\
$1999-2000$ & $1,249,922$ & 12,128 & $0.97 \%$ & 74 \\
$2000-2001$ & $1,268,406$ & 14,899 & $1.17 \%$ & 91
\end{tabular}

Source: North Carolina Department of Public Instruction 
Table 2: Means of Distance Measures

\begin{tabular}{lccc} 
Measure & $\mathbf{1 9 9 7 - 1 9 9 8}$ & $\mathbf{1 9 9 8 - 1 9 9 9}$ & $\mathbf{1 9 9 9 - 2 0 0 0}$ \\
\hline \multicolumn{4}{c}{ Continuous } \\
Distance (km) & 32.036 & 27.322 & 21.426 \\
Log (Distance) & 3.180 & 2.970 & 2.698 \\
\multicolumn{4}{c}{ Indicators } \\
Within $5 \mathrm{~km}$ & 0.093 & 0.142 & 0.193 \\
Within $10 \mathrm{~km}$ & 0.178 & 0.265 & 0.350 \\
Within $15 \mathrm{~km}$ & 0.272 & 0.366 & 0.480 \\
Within $20 \mathrm{~km}$ & 0.353 & 0.454 & 0.590 \\
Within 25 km & 0.425 & 0.539 & 0.694 \\
Within County & 0.329 & 0.464 & 0.570
\end{tabular}


Table 3: Achievement of Traditional Schools

\begin{tabular}{lcccc} 
& \multicolumn{2}{c}{ Performance Composite } & \multicolumn{2}{c}{ Increase from Previous Year } \\
Year & Mean & Std. Dev. & Mean & Std. Dev. \\
\hline $1996-1997$ & 66.93 & 11.34 & & \\
$1997-1998$ & 71.11 & 10.37 & 4.18 & 5.43 \\
$1998-1999$ & 73.69 & 9.88 & 2.58 & 4.76 \\
$1999-2000$ & 74.80 & 9.94 & 1.12 & 4.52
\end{tabular}

Source: North Carolina Department of Public Instruction 
Table 4: Summary Statistics

\begin{tabular}{lcc} 
Variable & Mean & Std Dev \\
\hline Proportion of Students Hispanic & 0.033 & 0.042 \\
Proportion of Students Free Lunch Eligible & 0.382 & 0.194 \\
Proportion of Students African-American & 0.319 & 0.247 \\
Student-Faculty Ratio & 15.216 & 2.438 \\
Enrollment of School & 566.564 & 229.276 \\
Performance Composite & 71.632 & 10.828 \\
Log (Performance Composite) & 4.273 & 0.163 \\
\hline
\end{tabular}


Table 5: Cross-Sectional IV Models

\begin{tabular}{lccc} 
Year & $\mathbf{1 9 9 7 - 1 9 9 8}$ & $\mathbf{1 9 9 8 - 1 9 9 9}$ & $\mathbf{1 9 9 9 - 2 0 0 0}$ \\
\hline Distance in km & $-4 \times 10^{-5}$ & $-2 \times 10^{-4 *}$ & $-1 \times 10^{-4}$ \\
& $\left(8 \times 10^{-5}\right)$ & $\left(8 \times 10^{-5}\right)$ & $\left(8 \times 10^{-5}\right)$ \\
Log(Distance) & -0.003 & -0.002 & $-0.007^{* *}$ \\
& $(0.002)$ & $(0.002)$ & $(0.002)$ \\
Charter within 10 km & $0.012^{*}$ & -0.002 & $0.018^{* *}$ \\
& $(0.006)$ & $(0.005)$ & $(0.004)$ \\
Charter within 20 km & $0.012^{*}$ & 0.004 & $0.010^{* *}$ \\
& $(0.005)$ & $(0.004)$ & $(0.004)$ \\
Charter In County & $0.013^{* *}$ & 0.003 & $0.008^{*}$ \\
& $(0.005)$ & $(0.004)$ & $(0.004)$ \\
\hline Observations & 1,286 & 1,307 & 1,307
\end{tabular}

Dependent Variable: Log(Performance Composite)

Standard errors in parentheses.

* Significant at $5 \%$;* Significant at $1 \%$.

Each cell contains the parameter estimate on the distance measure from a regression using data only from the indicated year with the corresponding distance variable as the only included distance measure. Thus, the table reports an estimate for $3 \times 5=15$ regressions.

Other included regressors include the percent of the students that are African-American, Hispanic, and free lunch eligible, the county population density, school enrollment, and the natural log of the lagged performance score (instrumented by the natural log of the twice lagged score).

The sample size in 1997-98 is less than 1,307 due to missing data for the twice-lagged score. 
Table 6: Arellano-Bond IV Models

\begin{tabular}{|c|c|c|c|c|c|c|c|}
\hline & $(1)$ & $(2)$ & $(3)$ & $(4)$ & $(5)$ & $(6)$ & $(7)$ \\
\hline Log(Distance) & $\begin{array}{l}-0.003 \\
(0.003) \\
\end{array}$ & & & & & & \\
\hline Charter within 5 kilometers & & $\begin{array}{c}0.011 \\
(0.006)\end{array}$ & & & & & \\
\hline Charter within 10 kilometers & & & $\begin{array}{l}0.010^{*} \\
(0.005)\end{array}$ & & & & \\
\hline Charter within 15 kilometers & & & & $\begin{array}{l}0.010^{*} \\
(0.005)\end{array}$ & & & \\
\hline Charter within 20 kilometers & & & & & $\begin{array}{l}0.010^{*} \\
(0.004)\end{array}$ & & \\
\hline Charter within 25 kilometers & & & & & & $\begin{array}{l}0.010^{*} \\
(0.004)\end{array}$ & \\
\hline Charter in County & & & & & & & $\begin{array}{c}0.008 \\
(0.004)\end{array}$ \\
\hline Log (Lagged Performance Composite) & $\begin{array}{l}0.415^{* *} \\
(0.028)\end{array}$ & $(0.022)$ & $\begin{array}{l}0.634^{* *} \\
(0.022)\end{array}$ & $\begin{array}{l}0.637^{* *} \\
(0.022)\end{array}$ & $\begin{array}{l}0.638^{* *} \\
(0.022)\end{array}$ & $\begin{array}{l}0.638^{* *} \\
(0.022)\end{array}$ & $\begin{array}{l}0.635^{* *} \\
(0.022)\end{array}$ \\
\hline Percent of Students Hispanic & $\begin{array}{c}-0.246^{*} \\
(0.100)\end{array}$ & $\begin{array}{c}-0.316^{* *} \\
(0.106)\end{array}$ & $\begin{array}{c}-0.314^{* *} \\
(0.106)\end{array}$ & $\begin{array}{c}-0.315^{* *} \\
(0.106)\end{array}$ & $\begin{array}{c}-0.311^{* *} \\
(0.106)\end{array}$ & $\begin{array}{c}-0.310^{* *} \\
(0.106)\end{array}$ & $\begin{array}{c}-0.310^{* *} \\
(0.106)\end{array}$ \\
\hline Percent of Students Free Lunch Eligible & $\begin{array}{l}0.066^{* *} \\
(0.026)\end{array}$ & $\begin{array}{l}0.119^{* *} \\
(0.027)\end{array}$ & $\begin{array}{l}0.118^{* *} \\
(0.027)\end{array}$ & $\begin{array}{l}0.119^{* *} \\
(0.027)\end{array}$ & $\begin{array}{l}0.120^{* *} \\
(0.027)\end{array}$ & $\begin{array}{l}0.119^{* *} \\
(0.027)\end{array}$ & $\begin{array}{l}0.118^{* *} \\
(0.027)\end{array}$ \\
\hline Percent of Students African-American & $\begin{array}{c}-0.359^{* *} \\
(0.046)\end{array}$ & $\begin{array}{c}-0.381^{* *} \\
(0.052)\end{array}$ & $\begin{array}{c}-0.381^{* *} \\
(0.052)\end{array}$ & $\begin{array}{c}-0.379^{* *} \\
(0.052)\end{array}$ & $\begin{array}{c}-0.380^{* *} \\
(0.052)\end{array}$ & $\begin{array}{c}-0.380^{* *} \\
(0.052)\end{array}$ & $\begin{array}{c}-0.378^{* *} \\
(0.052)\end{array}$ \\
\hline Student-Faculty Ratio & $\begin{array}{l}-0.002 \\
(0.001)\end{array}$ & $\begin{array}{l}-0.002 \\
(0.001)\end{array}$ & $\begin{array}{c}-0.002 \\
(0.001)\end{array}$ & $\begin{array}{c}-0.002 \\
(0.001)\end{array}$ & $\begin{array}{l}-0.002 \\
(0.001)\end{array}$ & $\begin{array}{l}-0.002 \\
(0.001)\end{array}$ & $\begin{array}{l}-0.002 \\
(0.001)\end{array}$ \\
\hline Constant & $\begin{array}{l}0.007^{* *} \\
(0.002)\end{array}$ & $\begin{array}{c}-0.035^{* *} \\
(0.003)\end{array}$ & $\begin{array}{c}-0.035^{* *} \\
(0.003)\end{array}$ & $\begin{array}{c}-0.035^{* *} \\
(0.003)\end{array}$ & $\begin{array}{c}-0.035^{* *} \\
(0.003)\end{array}$ & $\begin{array}{c}-0.035^{* *} \\
(0.003)\end{array}$ & $\begin{array}{c}-0.035^{* *} \\
(0.003)\end{array}$ \\
\hline
\end{tabular}

Standard errors in parentheses.

* Significant at $5 \%$; ${ }^{* *}$ Significant at $1 \%$.

Dependent Variable: Natural Log of Performance Composite)

$N=1,307$ in all regressions.

Models also include year indicators.

Each regression contains four years of data except for the first column, which contains only three years because distance is infinite in $1996-1997$. 
Table 7: Maximum Likelihood Models

\begin{tabular}{|lcc|}
\hline & \multicolumn{2}{c|}{ Points of Support } \\
\hline Distance & 1 point & 4 points \\
\hline \hline $5 \mathrm{~km}$ & $0.0106^{* *}$ & $0.0107^{* *}$ \\
& $(0.0028)$ & $(0.0028)$ \\
$10 \mathrm{~km}$ & $0.0093^{* *}$ & $0.0089^{* *}$ \\
& $(0.0024)$ & $(0.0024)$ \\
$15 \mathrm{~km}$ & $0.0067^{* *}$ & $0.0065^{* *}$ \\
& $(0.0024)$ & $(0.0024)$ \\
$20 \mathrm{~km}$ & $0.0090^{* *}$ & $0.0088^{* *}$ \\
& $(0.0023)$ & $(0.0024)$ \\
$25 \mathrm{~km}$ & $0.0055^{*}$ & $0.0055^{*}$ \\
& $(0.0024)$ & $(0.0024)$ \\
\hline
\end{tabular}

Each cell represents a separate regression in which the given variable is the only distance indicator included. $N=1,307$ schools in all cases.

**: Significant at 1 percent; $*$ : Significant at 5 percent.

Estimated standard errors are in parentheses.

"Points of support" specifies the number of discrete points of heterogeneity specified in the model. "1 point" assumes that there is no time-invariant heterogeneity.

Each model also includes the logarithm of the lagged performance composite, the proportion of the students that are Hispanic, African-American, and free lunch eligible, student to faculty ratio, enrollment, the county population density, and year indicators. 
Table 8: Relationship between Charter Competition and Average Performance Composites

\begin{tabular}{|c|c|c|}
\hline Cohort & Math & Reading \\
\hline \multicolumn{3}{|c|}{ rth Grade 1997-1998 } \\
\hline \multicolumn{3}{|c|}{ 8th Grade 1998-1999 } \\
\hline & 0.1289 & -0.167 \\
\hline & $(0.357)$ & $(0.214)$ \\
\hline \multicolumn{3}{|c|}{ 6th Grade 1997-1998 } \\
\hline \multicolumn{3}{|c|}{ rth Grade 1998-1999 } \\
\hline \multirow[t]{3}{*}{ 8th Grade } & 1999-2000 & \\
\hline & -0.2111 & -0.1381 \\
\hline & $(0.233)$ & $(0.140)$ \\
\hline \multicolumn{3}{|c|}{ 5th Grade 1997-1998 } \\
\hline \multicolumn{3}{|c|}{ 6th Grade 1998-1999 } \\
\hline \multirow[t]{3}{*}{ 7th Grade } & 1999-2000 & \\
\hline & 0.1592 & 0.0059 \\
\hline & $(0.407)$ & $(0.240)$ \\
\hline \multicolumn{3}{|c|}{ 4th Grade 1997-1998 } \\
\hline \multicolumn{3}{|c|}{ 5th Grade 1998-1999 } \\
\hline \multirow[t]{3}{*}{ 6th Grade } & 1999-2000 & \\
\hline & -0.3846 & -0.0717 \\
\hline & $(0.252)$ & $(0.157)$ \\
\hline \multicolumn{3}{|c|}{ 3rd Grade 1997-1998 } \\
\hline \multicolumn{3}{|c|}{ 4th Grade 1998-1999 } \\
\hline \multirow[t]{3}{*}{ 5th Grade } & 1999-2000 & \\
\hline & $-0.7604^{* *}$ & $-0.4347^{* *}$ \\
\hline & $(0.168)$ & $(0.121)$ \\
\hline \multicolumn{3}{|c|}{ 3rd Grade 1998-1999 } \\
\hline \multirow[t]{3}{*}{ 4th Grade } & 1999-2000 & \\
\hline & -0.4649 & $-0.4611^{*}$ \\
\hline & $(0.271)$ & $(0.207)$ \\
\hline
\end{tabular}

Standard errors are in parentheses. Each cell contains the parameter estimate on "a charter within 10 kilometers" indicator in a fixed-effect average score regression that also includes year indicators. The samples are cohorts of students over time. For example, the top panel follows those students in 7th grade in 1997-1998 to 8th grade 19981999, the cohort is not observed the following year, because students are not observed after 8th grade. The second row "6th grade 1997-1998" contains data for the three years 1997-1998 (6th grade), 1998-1999 (7th grade), and 1999-2000 (8th grade). 